Г.І. Лагутін ${ }^{1}$, О.В. Сальник ${ }^{1}$, С.В. Скіпор ${ }^{1}$, I.I. Кулинич ${ }^{2}$

${ }^{1}$ Харківський національний університет Повітряних Сил ім. І. Кожедуба, Харків

${ }^{2}$ Національний університет оборони України ім. I. Черняховського, Київ

\title{
АНАЛІЗ МОЖЛИВОСТІ ЗАСТОСУВАННЯ ВОЛЬТОДОДАТКОВИХ ТРАНСФОРМАТОРІВ ЯК ЗАСОБІВ КОМПЕНСАЦІЇ КОЛИВАНЬ НАПРУГИ В СИСТЕМАХ ЕЛЕКТРОПОСТАЧАННЯ СТАЦІОНАРНИХ ВІЙСЬКОВИХ АЕРОДРОМІВ
}

В статті проведений аналіз причин коливань напруги, які виникають в системах електропостачання стаціонарних військових аеродромів, та негативних наслідків для споживачів від ненормативних показників якості електроенергії. На підставі проведеного аналізу розглянуті способи регулювання напруги в системах електропостачання та розроблені пропозиції щзодо застосування регульованих вольтододаткових трансформаторів як засобів компенсації коливань напруги в системах електропостачання стаціонарних аеродромів Повітряних Сил.

Ключові слова: стаціонарний аеродром, системи електропостачання, коливання напруги, вольтододаткові трансформатори.

\section{Вступ}

Постановка проблеми. Стаття створена в рамках магістерської роботи за темою "Розробка засобів компенсації коливань напруги, які виникають в системах електропостачання стаціонарних військових аеродромів внаслідок вогневого впливу та дій диверсійних груп противника”. Досвід застосування сил (військ) під час проведення операції Об'єднаних сил (ООС) свідчить про те, що тільки висока надійність систем електропостачання (СЕП) військових аеродромів гарантує якісне виконання бойових завдань, покладених на авіацію Повітряних Сил Збройних Сил України [1].

При знищенні окремих елементів СЕП втрати напруги у споживачів можуть досягати 20-40 \%, що в свою чергу може викликати збої в роботі засобів забезпечення польотів авіації. Через це можуть бути знищені наземні об'єкти, що прикриваються авіацією, або інфраструктура самого військового аеродрому [2]. Тому мають впроваджуватися засоби компенсації коливань напруги для підтримання рівня напруги живлення споживачів якомога ближче до номінального значення. Це дозволить підвищити ефективність застосування родів авіації ї при веденні бойових дій у зоні ООС.

Аналіз останніх досліджень і публікацій. Аналіз СЕП військових аеродромів показав, що існуючі засоби регулювання напруги не пристосовані для швидкого реагування на коливання напруги, які можуть виникнути внаслідок аварій трансформаторів або ліній електропередачі [3-8]. Враховуючи переваги та недоліки методів регулювання напруги, визначено, що для регулювання напруги СЕП військового аеродрому в умовах проведення ООС, доцільно застосовувати спосіб примусової зміни напруги в кінці лінії живлення. Для реалізації цього способу можуть бути запропоновані такі засоби, як регульовані трансформатори та вольтододаткові трансформатори.

Зазвичай для регулювання напруги в електричних мережах застосовують регульовані силові трансформатори 3 перемикачами ПБЗ (перемикання без збудження) або РПН (регулювання під навантаженням). Перемикачі ПБЗ вимагають відключення споживачів на час перемикання, а перемикачі РПН мають обмежену швидкодію. Крім того, перемикачі обох типів $є$ контактними, що обумовлює їх порівняно невисоку надійність.

Тому актуальним $є$ проведення досліджень, спрямованих на впровадження вольтододаткових трансформаторів з безконтактними швидкодіючими перемикачами коефіцієнта трансформації, що дозволить покращити показники якості електричної енергії для відповідальних споживачів військових аеродромів, i, як наслідок, підвищити рівень боєготовності авіаційних військових частин.

Мета статті. Метою роботи є дослідження можливостей застосування вольтододаткових трансформаторів як засобів компенсації коливань напруги в СЕП стаціонарних військових аеродромів, спрямованих на підвищення рівня боєготовності авіаційних військових частин.

\section{Виклад основного матеріалу}

Для забезпечення електроенергією відповіда- 
льних споживачів військових аеродромів застосовують СЕП, до складу яких входять трансформаторні підстанції 10 (6)/0,4 кВ, резервні електростанції, силові кабельні лінії високої та низької напруги [9].

Внаслідок тривалої експлуатації, грозових та комутаційних перенапруг, а також через вогневий вплив та дії диверсійних груп противника елементи СЕП можуть зазнати пошкоджень та вийти з ладу. Відновлене дією релейного захисту та системної автоматики електропостачання може бути організоване через обхідні лінії електропередачі, які зазвичай мають більшу довжину або менший переріз, ніж основні. Елементи СЕП, що залишилися в роботі, при цьому будуть працювати з перевантаженням. Це може призвести до збільшення втрат напруги в електричній мережі та до зниження напруги у споживачів.

Протяжність мереж і кількість трансформаторних підстанцій сучасних СЕП військових аеродромів такі, що при знищенні окремих елементів СЕП внаслідок вогневого впливу противника втрати напруги у споживачів можуть досягати 20-40 \%. Це означає, що без застосування спеціальних заходів в умовах проведення ООС щодо регулювання напруги в мережах забезпечити необхідну якість напруги на шинах електроприймачів практично неможливо. Відхилення показників якості електроживлення відповідальних споживачів понад припустимі норми призводять до змін технічних показників роботи обладнання і в якихось моментах можуть стати чинником порушення його працездатності.

Дуже чутливими до зміни напруги є освітлювальні установки світлосигнальної системи аеродрому. При зниженні напруги на 10 \% світловий потік зменшується на $30 \%$, а при підвищенні напруги на 10 \% термін служби ламп зменшується в 4 рази.

Негативно впливають коливання напруги й на роботу радіолокаційних засобів аеродрому, таких як оглядовий радіолокатор, радіотехнічна система ближньої навігації, радіолокаційна система посадки, тощо. Під впливом коливань напруги приймальнопередавальні пристрої забезпечують меншу точність видачі інформації про дальність та швидкість повітряних суден. При зниженні напруги на затискачах асинхронного двигуна на $10 \%$ обертаючий момент зменшується пропорційно квадрату підведеної напруги, тобто на 19 \%, що призводить до збільшення ковзання на $27 \%$, зниження швидкості обертання електродвигуна, як наслідок, до зменшення точності визначення кутових координат літака.

Найбільш чутливі до відхилення напруги сучасні радіоелектронні пристрої, ЕОМ, схеми автоматики, побудовані на інтегральних мікросхемах, у яких допустиме відхилення заходиться в межах від $-0,5 \%$ до $+1 \%$ від номінального значення [10].

Тому для забезпечення надійної роботи відпо- відальних споживачів у складі СЕП військових аеродромів мають бути передбачені швидкодіючі засоби компенсації коливань напруги.

Для визначення причин втрат напруги при розподілі електроенергії розглянемо один із можливих варіантів СЕП, представлений на рис. $1, a$. Передача енергії від генератора $G$ до електроприймачів здійснюється лініями електропередачі. 3 усієї СЕП виділимо лінію Л1. Еквівалентна схема заміщення цієї лінії зображена на рис. $1, \sigma$. Тут величинами $R_{\text {л }}$ i $X_{\text {л }}$ представлені активний і реактивний опори лінії електропередачі і трансформаторів Т1 і Т2, величинами $U_{\Gamma}, U_{\text {н }}$ - генераторна напруга на шинах електростанції і напруга на шинах навантаження $Z_{\mathrm{H}}$, величинами $I_{\text {л}}, I_{\mathrm{H}}-$ струм у лінії електропередачі, який дорівнює струму навантаження.

При протіканні струму навантаження в лінії електропередачі мають місце падіння напруги на активному $R_{\text {л }}$ i реактивному $X_{\text {л }}$, опорах, через що величина напруги на навантаженні $U_{\text {н }}$ буде менше величини напруги на шинах електростанції $U_{\mathrm{r}}$. Для еквівалентної схеми заміщення електропередачі рис. 1, б рівняння балансу напруги можна представити у вигляді геометричної суми

$$
\dot{U}_{\Gamma}=\dot{U}_{H}+R_{\pi} \dot{I}_{л}+\dot{J} X_{ת} \dot{I}_{л} .
$$

На рис. 2 зображена векторна діаграма струмів і напруг, яка ілюструє вираз (1). Допускаючи, що характер і величина навантаження відомі, легко визначити напрям (кут $\varphi$ ) і величину струму в лінії $I_{л}$, який дорівнює струму навантаження $I_{\mathrm{H}}$, і знайти його активну $I_{\mathrm{a}}$ i реактивну $I_{\mathrm{p}}$ складові. 3 векторної діаграми рис. 2 видно, що величина напруги $\Delta U_{\text {л }}$ визначається довжиною вектора $\mathrm{AC}$, яка 3 достатньою для практичних розрахунків точністю може бути представлена проекцією вектора АС на напрям вектора $\dot{U}_{H}$, тобто представлена у вигляді суми:

$$
\Delta U_{\pi}=R_{\pi} I_{\pi} \cos \phi+X_{\pi} I_{\pi} \sin \phi=R_{\pi} I_{a}+X_{\pi} I_{p} .
$$

Помноживши і поділивши праву частину виразу (2) на величину $U_{\text {н }}$, отримаємо:

$$
\Delta U_{\pi}=\frac{R_{\pi} P_{a}+X_{л} Q_{p}}{U_{H}},
$$

де $P_{\mathrm{a}}, Q_{\mathrm{p}}$ - відповідно активна і реактивна потужності навантаження.

3 (2) і (3) витікає, що втрати напруги в лінії електропередачі i трансформаторах залежать від активного $R_{\text {л }}$ і реактивного $X_{\text {л }}$ опорів мережі і споживаної електроприймачами потужності.

Відомо, що для підтримки в СЕП значень напруги в заданих межах використовують такі види регулювання напруги, як централізоване загальне, централізоване групове та децентралізоване (місцеве) регулювання напруги (рис. 1).

Для реалізації того чи іншого виду регулювання напруги в СЕП застосовують такі основні спосо- 
би: примусова зміна напруги на живлячому кінці лінії за рахунок автоматичного регулювання збудження синхронних генераторів електростанцій чи застосування регульованих трансформаторів; зміна параметрів електричної мережі за рахунок компенсації іiі реактивного опору шляхом вмикання послі- довно 3 навантаженням реакторів чи конденсаторів послідовно-ємнісної компенсації; генерування реактивної потужності в СЕП за рахунок підключення паралельно навантаженню різних компенсуючих пристроїв (конденсаторів, силових дроселів, синхронних компенсаторів) [11].

a)

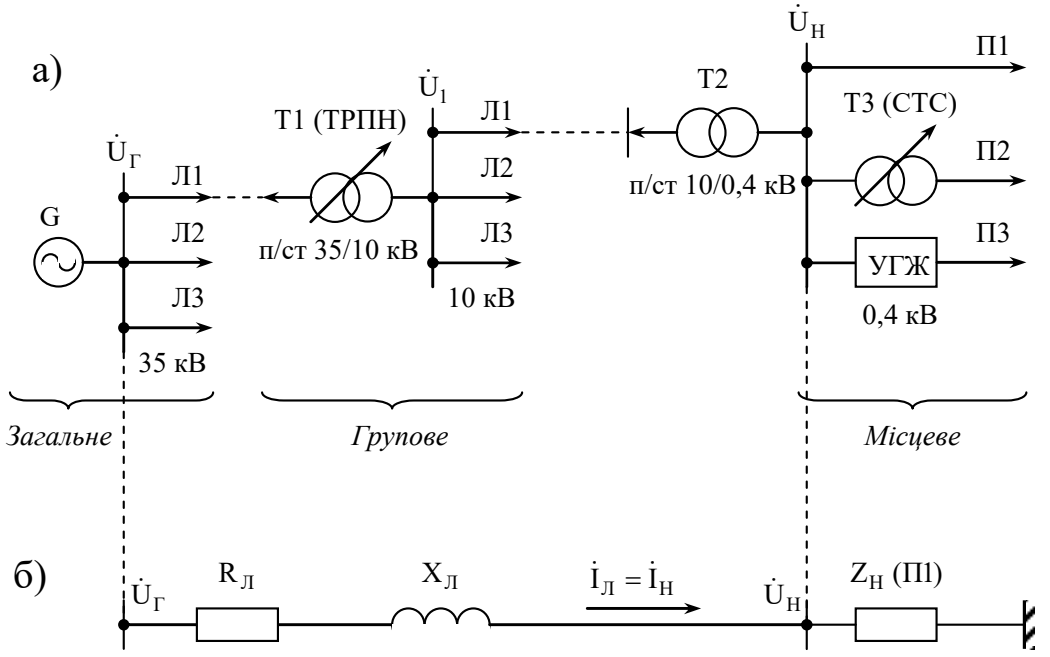

б)

Рис. 1. Схема системи електропостачання Джерело: розроблено авторами за даними [11].

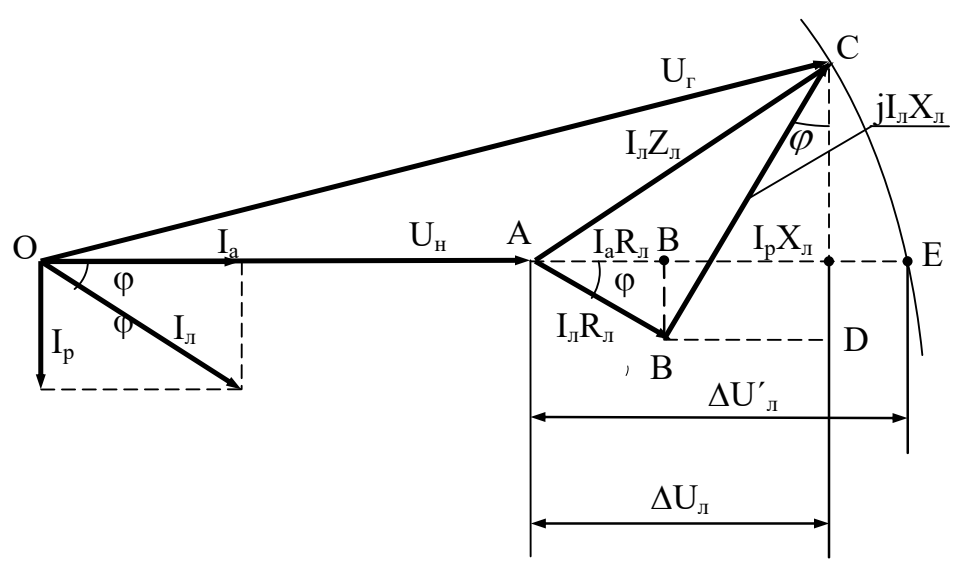

Рис. 2. Векторна діаграма струмів і напруг Джерело: розроблено авторами за даними [11].

Проведений аналіз показав, що для регулювання напруги СЕП військового аеродрому доцільно застосовувати спосіб примусової зміни напруги в кінці лінії живлення з використанням регульованих

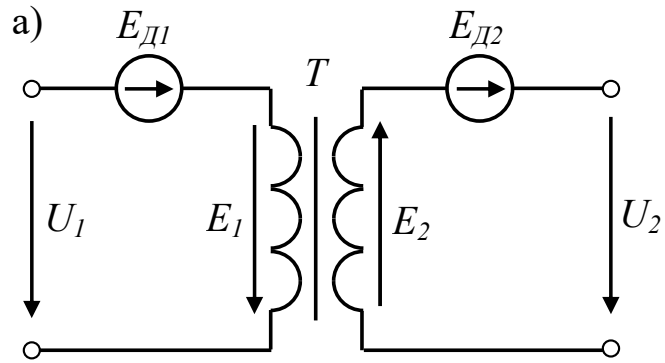

трансформаторів. У найбільш загальному випадку регульований трансформатор можливо подати у вигляді пристрою, зображеного на рис. 3. б)

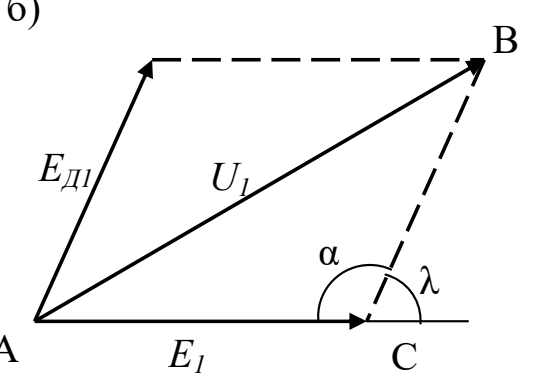

Рис. 3. Узагальнена схема і векторна діаграм трансформатора, що регулюється Джерело: розроблено авторами. 
Згідно 3 рис. 3 напруги $\dot{U}_{1}$ i $\dot{U}_{2}$ можна представити у вигляді геометричних сум

$$
\dot{U}_{1}=\dot{E}_{1}+\dot{E}_{g 1 ;} \quad \dot{U}_{2}=\dot{E}_{2}+\dot{E}_{g 2},
$$

де $\dot{E}_{1}, \dot{E}_{2}-$ електрорушійні сили первинної і вторинної обмоток трансформатора;

$\dot{E}_{g 1}, \dot{E}_{g 2}$ - додаткові електрорушійні сили, штучно введені в кола первинної і вторинної обмоток.

Ураховуючи відоме співвідношення для визначення електрорушійних сил обмоток трансформаторів $E_{i}=K W_{i} \Phi_{m i}$ та визначивши довжину векторів $\dot{U}_{1}$ і $\dot{U}_{2}$ за теоремою косинусів, одержимо аналітичний вираз для визначення коефіцієнта перетворення регульованого трансформатора [13]:

$$
K_{n p}=\sqrt{\frac{\left(K W_{1} \Phi_{m i}\right)^{2}+E_{g 1}{ }^{2}+2 E_{g 1} K W_{1} \Phi_{m 1} \cos \lambda_{1}}{\left(K W_{2} \Phi_{m 2}\right)^{2}+E_{g 2}{ }^{2}+2 E_{g 2} K W_{2} \Phi_{m 2} \cos \lambda_{2}}},
$$

де $\lambda_{1}, \lambda_{2}-$ кути зсуву фаз між додатковими електрорушійними силами та електрорушійними силами обмоток трансформатора.

3 (5) можна визначити способи зміни коефіцієнта перетворення трансформатора, а отже і способи регулювання напруги: зміною числа витків W; перерозподілом магнітного потоку $\Phi$; зміною величини додаткової електрорушійної сили $\mathrm{E}_{\mathrm{gi}}$; зміною кута зсуву фаз $\lambda$ між додатковою та основною електрорушійними силами обмотки трансформатора.
В існуючих СЕП військових аеродромів застосовуються трансформатори із східчастою зміною числа витків 3 перемикачем відгалужень типу ПБЗ. Регулювання таких трансформаторів може здійснюватися тільки вручну й тільки після відключення відповідних споживачів.

Трансформатори 3 плавною зміною числа витків недоцільно використовувати на великих потужностях через руйнування ковзного контакту. Трансформатори з РПН не здатні здійснювати компенсацію короткочасних коливань напруги через те, що зміна вихідної напруги відбувається тільки східчасто та $з$ витримкою часу. Достатньо перспективним можна вважати трансформатор 3 тиристорною комутацією відгалужень, але це передбачає реконструкцію існуючих трансформаторів шляхом заміни механічного перемикача ПБЗ на безконтактний тиристорний комутатор.

Застосування трансформаторів, що регулюються рухомою обмоткою, принципово потребує абсолютно іншої конструкції трансформатора, до того ж, регулювання здійснюється за рахунок механічного переміщення рухомої обмотки, що знижує надійність системи.

Використання трансформаторів 3 напівпровідниковою комутацією обмоток, як і в попередньому випадку, вимагає повної заміни трансформаторів у СЕП; недоліком також можна вважати несинусоїдність вихідної напруги. a)

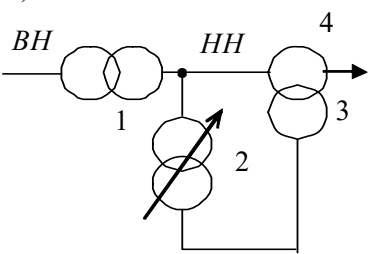

б)

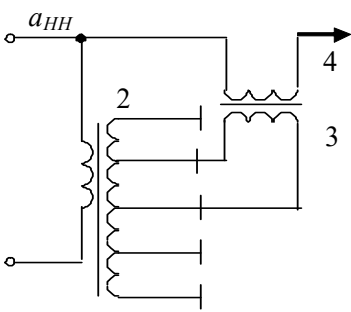

B)

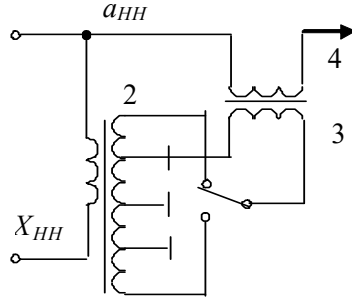

г)

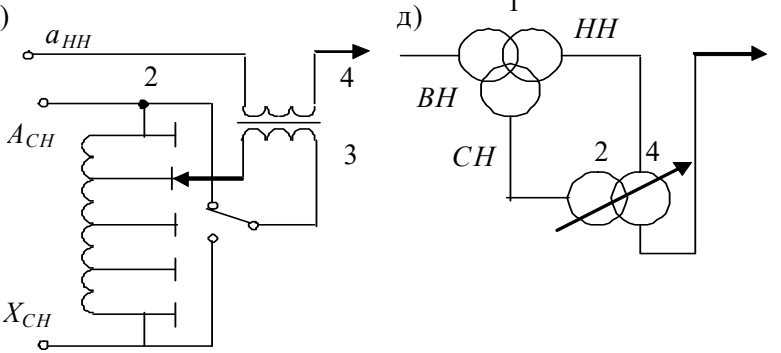

e)

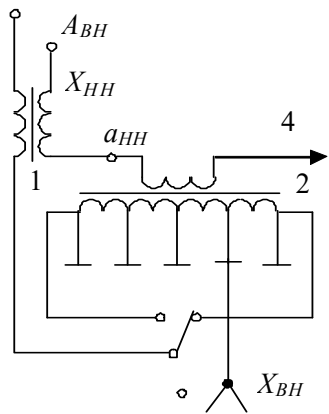

Рис. 4. Вольтододаткові трансформатори Джерело: розроблено авторами за даними [12].

Традиційні вольтододаткові трансформатори 3 подовжнім або поперечним регулюванням недоці- льно застосовувати для компенсації коливань напруги, які виникають в СЕП військових об'єктів 
внаслідок дії зброї та диверсійних груп противника через те, що регулювання напруги може здійснюватися тільки східчасто.

У найбільш загальному випадку вольтододатковий трансформатор (рис. $4, a-8$ ) містить регульований трансформатор 2, підключений після силового трансформатора 1 до лінії, в якій здійснюється регулювання напруги, і послідовний трансформатор, первинна обмотка 3 якого отримує живлення від регульованого трансформатора 2, а вторинна 4 ввімкнена послідовно в мережу, де відбувається регулювання напруги [12].

На рис. 4, г-е наведені приклади вмикання во-
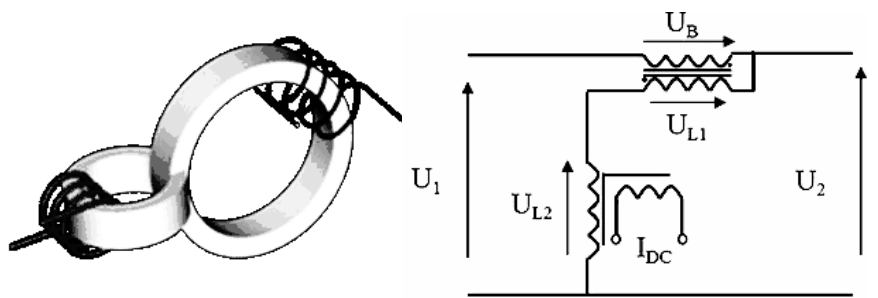

льтододаткового трансформатора до триобмоткового силового трансформатора. Власна потужність вольтододаткових трансформаторів не перевищує 10-15 \% від прохідної потужності нерегульованого трансформатора.

Останнім часом викликає інтерес використання вольтододаткових трансформаторів 3 плавним регулюванням напруги.

Основою конструкції є запатентована норвезькою компанією Magtech технологія MCI (Magtech Controllable Inductance) - керована котушка індуктивності (рис. 5) [14-16].

Рис. 5. Вольтододаткові трансформатори

Джерело: розроблено авторами за даними [14].

Зазвичай зміна індуктивності здійснюється за рахунок зміни повітряного зазору в феромагнітному осерді. Через те, що механічна зміна повітряного зазору трудомістка та ненадійна, фірма Magtech запропонувала створення віртуального повітряного зазору за рахунок підмагнічування осердя постійним струмом (технологія МCI - керована котушка індуктивності). Таке поперечне підмагнічування приводить, як і повітряний зазор, до зменшення магнітного потоку й, отже, індуктивності.При подачі максимального постійного струму $I_{\mathrm{DC}}$ виникає мінімальна індуктивність і мінімальний опір. Зменшується падіння напруги $U_{\mathrm{L} 1}$, що збільшуе падіння напруги $U_{\mathrm{L} 2}$. Через автотрансформатор додаткова напруга $U_{\mathrm{B}}$, передається на його послідовну обмотку. Завдяки цьому можливо змінювати напруги $U_{\mathrm{B}}$ таким чином, щоб утримувати напругу $U_{2}$ в допустимих межах.

Постійний струм для поперечного намагнічування подається через тиристорний перетворювач. Проводиться внутрішнє вимірювання струму й напруги всіх трьох зовнішніх провідників, потім їх обробка в контролері. Регулювання напруги здійснюється плавно від 0 до мінус $7 \%$, індивідуально для кожної фази. Дуже малий час реагування всієї системи (300 мс), забезпечує якість електроенергії в низьковольтній мережі при всіх станах енергопотоку. Функція байпаса дозволяє автоматичне перемикання регулюючої функції пристрою. Якщо живлення в низьковольтну мережу подається з електромережі або потужність зворотної подачі 3 джерел енергії низька, то стабілізатор напруги включається пасивно через байпасний контактор, і регулювання не проводиться. Це дозволяє досягти найкращого ККД і значно знизити додаткові втрати. Перемикання на активний режим здійснюється автоматично через блок керування пристрою. Подібні пристрої регулювання напруги для мережі 0,4 кВ змінного струму розраховані на потужність 130 кВА або 260 кВА 3 гарантованою роботою в режимі навантаження $160 \%$ від номінального до шести годин для обох варіантів, що задовольняє вимоги переважної більшості відповідальних споживачів військових аеродромів.

\section{Висновки}

Проведений аналіз можливостей застосування вольтододаткових трансформаторів як засобів компенсації коливань напруги в СЕП стаціонарних військових аеродромів показав наступне.

1. При знищенні окремих елементів СЕП втрати напруги у споживачів можуть досягати 20-40\%, що в свою чергу може викликати збої в роботі засобів забезпечення польотів авіації. Через це можуть бути знищені наземні об'єкти, що прикриваються авіацією, або інфраструктура самого військового аеродрому.

Тому мають впроваджуватися засоби компенсації коливань напруги для підтримання рівня напруги живлення споживачів якомога ближче до номінального значення.

2. Враховуючи переваги та недоліки методів регулювання напруги визначено, що для регулювання напруги СЕП військового аеродрому в умовах проведення ООС, доцільно застосовувати спосіб примусової зміни напруги в кінці лінії живлення. 
Для реалізації цього способу можуть бути запропоновані такі засоби, як регульовані трансформатори та вольтододаткові трансформатори.

3. Традиційні вольтододаткові трансформатори 3 подовжнім або поперечним регулюванням недоцільно застосовувати для компенсації коливань напруги, які виникають в СЕП військових об'єктів внаслідок дії зброї та диверсійних груп противника через те, що регулювання напруги може здійснюватися тільки східчасто.

4. Використання удосконалених вольтододаткових трансформаторів 3 регулюванням напруги на основі технології МСI (керована котушка індуктивності), запатентованої норвезькою компанією Magtech є доцільним.

5. Регулювання напруги удосконалених вольтододаткових трансформаторів здійснюється плавно в достатньо широкому діапазоні, індивідуально для кожної фази; малий час реагування забезпечує якість електроенергії в низьковольтній мережі при всіх режимах роботи СЕП; номінальна потужність та перевантажувальна здатність таких пристроїв задовольняє вимоги переважної більшості відповідальних споживачів військових аеродромів.

\section{Список літератури}

1. Аналіз способів та засобів щодо зниження демаскуючих чинників пересувних електростанцій в умовах ведення бойових дій / Г.І. Лагутін, В.М. Уваров, Я.А. Смола, О.О. Юр'єв // Наука і техніка Повітряних Сил Збройних Сил України. - 2020. - № 3(40). - С. 107-113. https://doi.org/10.30748/nitps.2020.40.12.

2. Визначення очікуваного впливу противника на системи електропостачання аеродромів у ході ведення бойових дій та рекомендації щодо їх відновлення / С.М. Новічонок, О.А. Усачова, О.Б. Куренко, А.О. Романюк, І.В. Терентьєва // Збірник наукових праць Харківського національного університету Повітряних Сил. - 2018. - № 4(58). C. 80-88. https://doi.org/10.30748/zhups.2018.58.11.

3. Лагутін Г.І. Застосування методу динамічного програмування для розв'язання задачі визначення оптимальної кількості джерел електричної енергії для споживачів військового аеродрому / Г.І. Лагутін, В.М. Лисенко // Наука і техніка Повітряних Сил Збройних Сил України. - 2011. - № 2(6). - С. 37-39.

4. Мурасов Р.К. Методика розрахунку імовірності успішної посадки літака / Р.К. Мурасов // Наука і техніка Повітряних Сил Збройних Сил України. - 2012. - № 3(9). - С. 53-57.

5. Лагутин Г.И. Особенности обоснования характеристик и показателей образцов электротехнических средств систем электроснабжения комплексов вооружения и военной техники / Г.И. Лагутин // Системи озброєння і військова техніка. - 2015. - № 4(44). - С. 21-23.

6. Моніторинг станів операційного середовища та багатоструктурних систем військового призначення при управлінні їх функціонуванням та структурною динамікою / Д.А. Гриб, Б.О. Демідов, Ю.Ф. Кучеренко, О.Г. Матющенко, О.О. Хмелевська // Збірник наукових праць Харківського національного університету Повітряних Сил. - 2019. № 1(59). - C. 14-25. https://doi.org/10.30748/zhups.2019.59.02.

7. Буданов П.Ф. Повышение надёжности функционирования энергообъектов на основе усовершенствования программно-технического комплекса автоматизированной подсистемы аварийной и предупредительной защиты / П.Ф. Буданов, К.Ю. Бровко, П.В. Васюченко // Збірник наукових праць Харківського національного університету Повітряних Сил. - 2016. - № 3(48). - С. 161-167.

8. Нор П.І. Методика оцінки технічного рівня зразків озброєння та військової техніки / П.І. Нор, П.В. Щипанський, С.Ю. Гогонянц // Системи озброєння і військова техніка. - 2014. - № 3(39). - С. 49-53.

9. Лагутін Г.І. Вдосконалення способів релейного захисту силових трансформаторів в системах електропостачання військових аеродромів, що залучаються для потреб ООС / Г.І. Лагутін, А.І. Кудрявський, С.М. Хабоша // Збірник наукових праць Харківського національного університету Повітряних Сил. - 2019. - № 2(60). - С. $126-132$. https://doi.org/10.30748/zhups.2019.60.16.

10. Пантєлєєва І.В. Визначення раціональних режимів роботи і експлуатації енергооб'єктів та електроприводів / І.В. Пантєлєєва // Збірник наукових праць Харківського національного університету Повітряних Сил. - 2015. - № 2(43). - C. 100-103.

11. Підвищення ефективності постачання електроенергії шляхом удосконалення роботи силових трансформаторів підстанцій енергосистеми / А.М. Панченко, А.В. Міністерський, С.М. Зарічняк, В.В. Калачова, М.П. Долина // Системи озброєння і військова техніка. - 2019. - № 2(58). - С. 92-101. https://doi.org/10.30748/soivt.2019.58.12.

12. Правила улаштування електроустановок. - Видання офіційне. Міненерговугілля України [Електронний ресурс]. - Х.: Форт, 2017. - 760 с. - Режим доступу: https:/enext.ua/upload/books/pueh-ukraina-2017.pdf.

13. Мушаров А.О. Апроксимація основної кривої намагнічування магнітопроводу силового трансформатору ступеневим поліномом третього ступеня / А.О. Мушаров // Системи озброєння і військова техніка. - 2013. - № 4(36). - С. 103-106.

14. Офіційний сайт PATENTS.GOOGLE.COM. System for voltage stabilization of power supply lines. - Режим доступу: https://patents.google.com/patent/US7180206B2/en.

15. Офіційний сайт FREEPATENTSONLINE.COM. Magnetically controlled inductive device. - Режим доступу: https://www.freepatentsonline.com/7026905.html.

16. Офіційний сайт PATENTS.JUSTIA.COM. Controllable transformer. - Режим доступу https://patents.justia.com/patent/7061356. 
Відомості про авторів:

\section{Лагутін Геннадій Іванович}

кандидат технічних наук доцент начальник кафедри

Харківського національного університету

Повітряних Сил ім. І. Кожедуба,

Харків, Україна

https://orcid.org/0000-0002-6337-1357

\section{Сальник Олег Вікторович}

старший науковий співробітник Харківського національного університету Повітряних Сил ім. І. Кожедуба,

Харків, Україна

https://orcid.org/0000-0002-2688-1198

\section{Скіпор Сергій Володимирович}

курсант Харківського національного університету

Повітряних Сил ім. І. Кожедуба,

Харків, Україна

https://orcid.org/0000-0001-9590-451X

\section{Кулинич Ігор Ігорович}

старший науковий співробітник Національного

університету оборони України ім. І. Черняховського,

Київ, Україна

https://orcid.org/0000-0001-5543-842X
Information about the authors:

\section{Hennadiy Lahutin}

Candidate of Technical Sciences Associate Professor

Head of Department of Ivan Kozhedub Kharkiv

National Air Force University,

Kharkiv, Ukraine

https://orcid.org/0000-0002-6337-1357

Oleh Sal'nyk

Senior Research Associate of Ivan Kozhedub Kharkiv

National Air Force University,

Kharkiv, Ukraine

https://orcid.org/0000-0002-2688-1198

\section{Sergiy Skipor}

Cadet of Ivan Kozhedub Kharkiv

National Air Force University,

Kharkiv, Ukraine

https://orcid.org/0000-0001-9590-451X

Igor Kulinich

Senior Research Associate of Ivan Chernyakhivsky

National University of Defense of Ukraine,

Kyiv, Ukraine

https://orcid.org/0000-0001-5543-842X

\title{
АНАЛИЗ ВОЗМОЖНОСТИ ПРИМЕНЕНИЯ ВОЛЬТОДОПОЛНИТЕЛЬНЫХ ТРАНСФОРМАТОРОВ КАК СРЕДСТВ КОМПЕНСАЦИИ КОЛЕБАНИЙ НАПРЯЖЕНИЯ В СИСТЕМЕ ЭЛЕКТРОСНАБЖЕНИЯ СТАЦИОНАРНЫХ ВОЕННЫХ АЭРОДРОМОВ
}

\section{Г.И. Лагутин, О.В. Сальник, С.В. Скипор, И.И. Кулинич}

В статье проведен анализ направлений совершенствования устройств релейной защиты силовых кабельных линий систем электроснабжения стационарных аэродромов Воздушных Сил, привлекаемых для нужд проведения Операции объединенных сил. На основании проведенного анализа рассмотрены функииональные особенности микропроиессорных устройств релейной защиты и системной автоматики и разработаны предложения по их применению для защить высоковольтных электрических сетей стаиионарных аэродромов Воздушных Сил.

Ключевые слова: стационарный аэродром, электрические сети, релейная защита, микропроцессорные терминалы защиты, молекулярный накопитель энергии.

\section{ANALYSIS OF THE POSSIBILITY OF USING VOLTAGE ADDITIONAL TRANSFORMERS AS MEANS OF COMPENSATION OF VOLTAGE VILLATIONS IN ELECTRICITY SUPPLY SYSTEMS FOR STATIONARY MILITARY AIRPORTS}

\author{
H. Lahutin, O. Sal'nik, S. Skipor, I. Kulinich
}

Electrical networks of military airfields, which are used during the Joint Forces operation, have a significant length, and as a result, significant vulnerability to long-range weapons and enemy sabotage groups. Relay protection and automation of electrical networks is the only way that allows quick localization of damage and, as a result, ensure the operation of the power supply system. Relay protection devices used today, in most cases, have limited performance due to exceeding the guaranteed service life and inadequate level of maintenance and repair. Therefore, it is relevant to conduct research aimed at the introduction of integrated devices for microprocessor relay protection. This will increase the survivability of the power supply systems of stationary airfields, the reliability of supply to responsible consumers of electrical energy, and, as a consequence, increase the level of Air Force combat readiness. The article discusses the possibilities of using modern relay protection devices, built on the basis of microprocessor terminals, to ensure the protection of power cable lines of military airfields power supply systems. The analysis of the requirements of the governing documents showed that two-stage current protection should be used to protect power cable lines, the first stage of which is made in the form of a current cutoff, and the second - in the form of overcurrent protection. The article compares two options for building a relay protection system. Calculations of short-circuit currents and settings for the operation of relay protection of power cable lines of military airfields have shown the possibility and expediency of using microprocessor relays to improve the reliability of power supply to military airfields.

Keywords: stationary airfield, electrical networks, relay protection, microprocessor protection terminals. 